\title{
The intensity of root colonization by phytopathogenic fungus and rhizobacterium depends on the genotype of tomatoes and abscisic acid
}

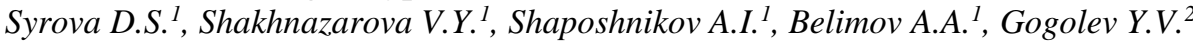

${ }^{1}$ All-Russian Research Institute of Agricultural Microbiology, Saint-Petersburg, Russia; ${ }^{2}$ Kazan Institute of Biochemistry and Biophysics, FRC Kazan Scientific Center of RAS, Kazan, Russia

E-mail: syr_daria@ro.ru

Key message. The intensity of root colonization by phytopathogenic fungus and rhizobacterium differs depending on the tomato genotype. Inoculation of wild-type tomatoes Ailsa Craig, but not of its ABA deficient mutant flacca, with Novosphingobium sp. P6W inhibits root colonization by Fusarium oxysporum MF-G284.

Keywords: phytopathogen, Fusarium, abscisic acid, PGPB, biocontrol

Infection of plants with phytopathogenic fungi and their following death is an actual problem in modern agriculture. Therefore, there is interest in rhizosphere bacteria that can neutralize the harmful effects of pathogens on plants and thereby avoid infection and plant death. In the rhizosphere of plants, there are bacteria that are antagonistic to phytopathogens, suppressing their activity using biocontrol mechanisms, such as competition for the habitat, production of antibiotics, toxins, siderophores, competition for nutrition by root exudates, as well as others not yet known. We assume that there is a mechanism associated with the opposite effect of these microorganisms on the hormonal status of plants. Abscisic acid (ABA) producing fungi were screened by UPLC methods (Waters) in isocratic mode in the acetonitrile:water:acetic acid (18\%:82\%:0.1\%) solvent system. ABA was determined at a wavelength of $265 \mathrm{~nm}$. Further in the work, vegetative experiment with vermiculite was used. We used tomato plants of two genotypes: Ailsa Craig cultivar and its ABA deficient mutant flacca. The plants were inoculated with the phytopathogenic fungus Fusarium oxysporum MF-G284, growthstimulating bacterium Novosphingobium sp. P6W, as well as with a combination of these microorganisms. Amount of fungus spores was counted using Goryaev's count chamber. The amount of cells in the bacterial culture was calculated by measuring the optical density on a Bio-Rad SmartSpec Plus spectrophotometer at a wavelength of $540 \mathrm{~nm}$. As an inoculum a fungal suspension $\left(1 \times 10^{5}\right.$ spores $\left./ \mathrm{ml}\right)$ and a bacterial suspension $\left(1 \times 10^{7}\right.$ cells $\left./ \mathrm{ml}\right)$ were used. After inoculation, the plants were grown in a phyto-room for 14 days at a temperature of $23^{\circ} \mathrm{C}$ under periodic illumination of 16 hours a day / 8 hours a night. The amount of microorganism's DNA on the tomato roots was determined using real-time qPCR method by the CFX96 Touch qPCR System DNA amplifier (Bio-Rad). Determining the intensity of colonization of tomato roots by the bacterium Novosphingobium sp. P6W by quantitative real-time PCR was performed for the first time. Inoculation of wild-type tomatoes by Novosphingobium sp. P6W inhibited root colonization by phytopathogenic fungi. Root colonization of tomato mutants flacca by fingus $F$. oxysporum occurred more intensively than colonization of wild-type tomato roots. Colonization of tomato roots by plant-growth promoting rhizobacteria Novosphingobium sp. P6W depended on the tomato genotype. In the roots of Ailsa-Craig inoculated with the bacterium Novosphingobium sp. P6W the bacterial DNA content was several times higher than in the roots of ABA biosynthesis mutant flacca. In the case of root inoculation with a combination of microorganisms, a significant decrease in the amount of fungal DNA was observed on the roots of wild type, but this effect was not observed on the roots of flacca tomatoes. These observations indicate the importance of phytohormones in the process of plant root colonization by the phytopathogenic fungus $F$. oxysporum and the bacterial strain Novosphingobium sp. P6W, as well as its ability to compete with phytopathogenic fungi.

This work was supported by the Russian Science Foundation (grants 17-14-01363 and 19-16-00097), Science and Higher Education Committee under the Government of St. Petersburg.

1. Шахназарова В.Ю., Феоктистова А.С., Чижевская Е.П., Вишневская Н.А., Струнникова О.К. (2012) Оптимизация способа выделения ДНК для идентификации и количественного определения Fusarium culmorum в корнях ячменя и пшеницы методом ПЦР. Микология и фитопатология. Т. 46 (4). С.287-292.

2. Belimov A.A., Dodd I.C., Safronova V.I., Dumova V.A., Shaposhnikov A.I., Ladatko A.G., Davies W.J. (2014) Abscisic acid metabolizing rhizobacteria decrease ABA concentrations in planta and alter plant growth. Plant Physiology and Biochemistry, № 74, 84-91.

3. Gogoleva N. E., Nikolaichik Y. A., Ismailov T. T. et al (2019) Complete genome sequence of the abscisic acid-utilizing strain Novosphingobium sp. P6W. 3Biotech, 9:94. 